\title{
Archaeobotanical investigations in the Aisne valley, northern France, from the Neolithic up to the early Middle Ages
}

\author{
Corrie Bakels \\ Faculty of Archaeology, Leiden University, P.O. Box 9515, 2300 RA Leiden, The Netherlands
}

Received July 9, 1998 / Accepted January 25, 1999

\begin{abstract}
Carbonized fruits and seeds retrieved during rescue excavations in the Aisne valley, France, and near surroundings are discussed. The time span covered is Neolithic through to the 6 th century A.D. The sequence starts with the crop plants grown by Bandkeramik farmers. A later innovation was the introduction of naked wheat by the Neolithic Cerny culture. The early Iron Age brought major innovations such as a diversification in crops and the appearance of pastures.
\end{abstract}

Key words: France - Aisne valley - Carbonized seeds Prehistory - Protohistory

\section{Introduction}

The river Aisne belongs to the drainage basin of the river Seine in northern France. Its source lies between Verdun and Reims, but the sector of the valley under study stretches from the small town of Neufchâtel in the east to the confluence of the river with the river Oise, near Compiègne, in the west (Fig. 1). A quarter of this distance the river flows through the rolling chalk landscape of Champagne. For the remaining distance the valley cuts through Tertiary limestone plateaux, forming a flat-bottomed corridor with steep sides. The valley floor is covered by gravel terraces with loam on top, and it is these terraces which were the focus of settlement from the early Neolithic through the early Middle Ages (Fig. 2 ). The plateaux are characterized by very little open water and a low water table; even today, they are sparsely settled.

The Aisne gravels are of great value for concrete manufacture and road building, and large-scale gravel extraction is destroying the landscape. From the seventies onwards, rescue excavations carried out by, mainly, the CNRS Equipe de Recherche Archéologique no 12, the University of Paris I and the Centre de Recherches archéologiques at Soissons, have tried to record as much of the past as possible. The University of Durham, England, has undertaken fieldwork focussing on the Late Iron Age and Gallo-Roman period.

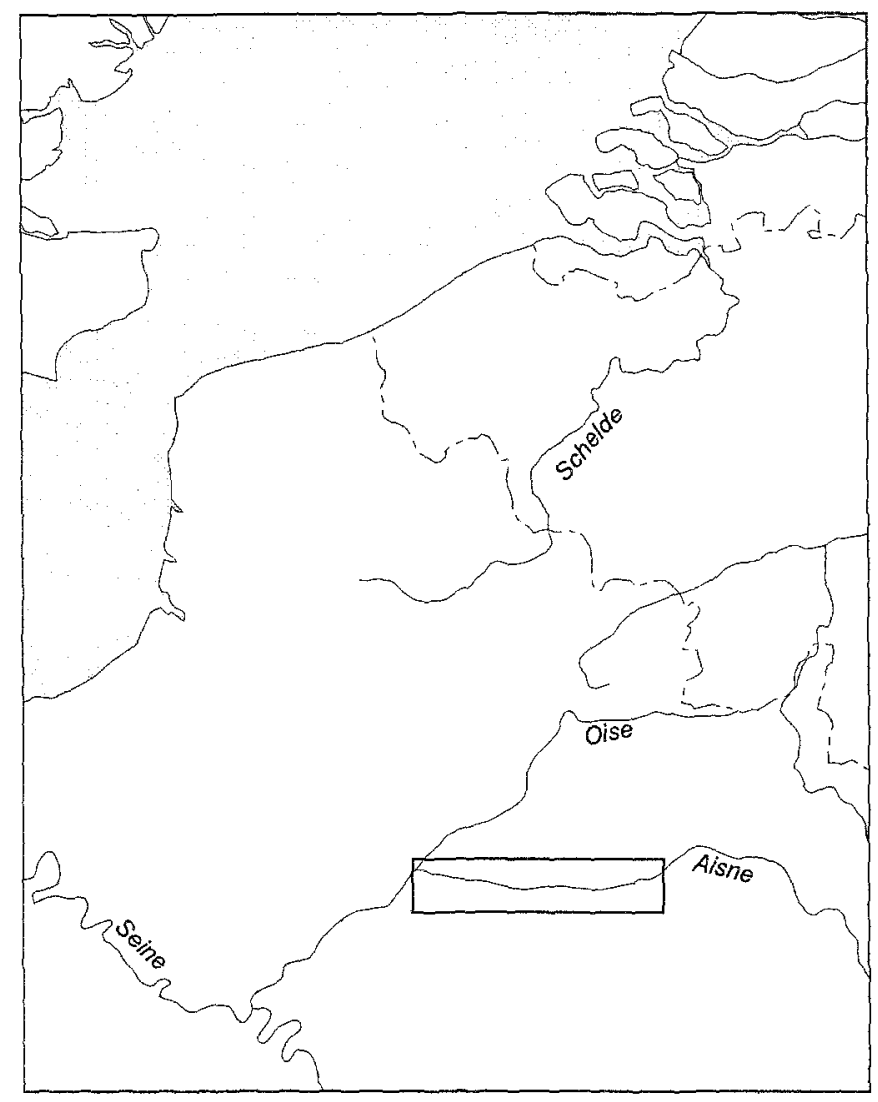

Fig. 1. North-west France; the rectangle indicates the study area

\section{Aim of this paper}

For more than fifteen years I have been studying seeds from samples collected during the investigations mentioned above. The aim of this paper is to provide a diachronous review of the presence or absence of crop plants found, and to present some general trends visible in the wild taxa. The analysis is based solely on carbonized remains. Waterlogged and mineralized remains are omitted because of their different taphonomy; their in- 


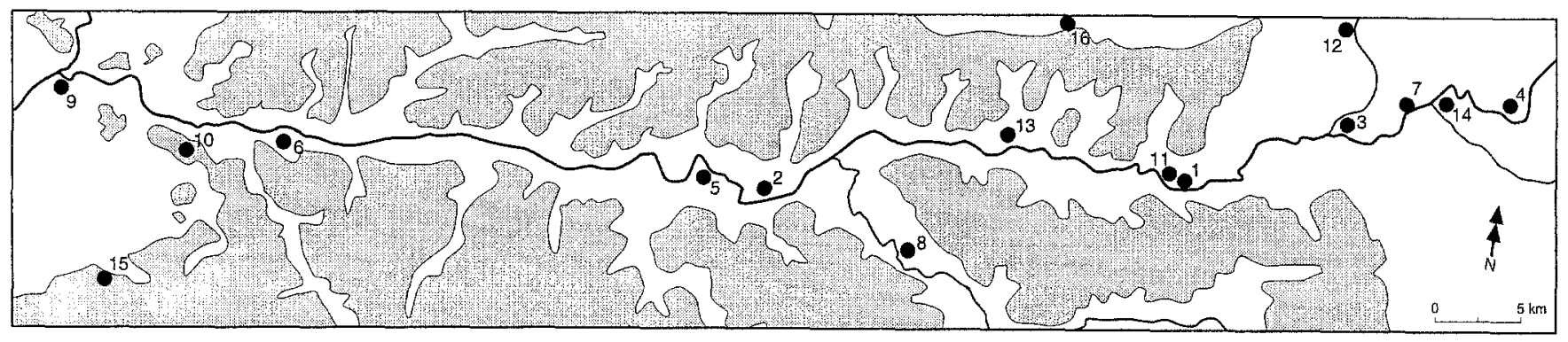

Fig. 2. Map of the Aisne valley with the sites mentioned in the text; shaded areas represent the limestone plateaux. 1 Cuiry-lèsChaudardes; 2 Bucy-le-Long; 3 Berry-au-Bac; 4 Menneville; 5 Villeneuve-St-Germain; 6 Trosly-Breuil; 7 Juvincourt; 8 Bazoches-sur-Vesle; 9 Compiègne; 10 Vieux-Moulin; 11 Beaurieux; 12 Damary; 13 Soupir; 14 Condé-sur-Suippe; 15 Champlieu; 16 Cerny-en-Laonnois

clusion would distort comparisons. Waterlogged material was restricted, up till now, to Iron Age and GalloRoman contexts.

I have considered whether it would be desirable to base the review exclusively on material obtained from rural sites. The inclusion of non-rural sites might bring in plants not produced in the Aisne valley and near surroundings, but imported from elsewhere. A close inspection of the socio-cultural setting and composition of the seed assemblages showed, however, no clear indications of imports. Therefore I decided to include the Michelsberg causewayed camp at Bazoches-sur-Vesle, the valley bottom oppida (large nucleated settlements) at Villeneuve-St.Germain and Condé-sur-Suippe, and the Gallo-Roman town of Champlieu in the review.

The span of time aimed at is early Neolithic up to and including the beginning of the Middle Ages. The cultural sequence in the Aisne valley is as follows: Bandkeramik (here known as Rubané récent du Bassin Parisien, 50004800 B.C., all dates are calibrated), Villeneuve-St. Germain culture (4800-4600 B.C.), Cerny (4600-4300 B.C.), late Rössen (4300-4000 B.C.), Michelsberg (4000-3500 B.C.), Seine-Oise-Marne followed by Bell Beaker (3500-2500 B.C.), early and middle Bronze Age (2500-1200 B.C.), late Bronze Age (1200-900 B.C.), Hallstatt C (900-600 B.C., in the Aisne valley quite related to the late Bronze Age), Hallstatt D and La Tène A (600-250 B.C.), La Tène B, C and D (250-20 B.C.), the Gallo-Roman period divided into early Gallo-Roman (1st Century A.D.), Haut Empire (2nd and 3rd Centuries A.D.) and Bas Empire (4th Century A.D.), and, finally, the early Middle Ages/Merovingian period (source: Pommepuy and Robert 1991; Haselgrove 1996).

\section{Materials and methods}

Only Neolithic and Iron Age sites, supplemented by one Gallo-Roman farm, have been sampled regularly and systematically. Other material has a more haphazard origin. Most samples were taken from pits and concern discarded waste. Only few represent primary fill, in all but one case the primary fill of a silo (storage pit). The exception is a late Bronze Age pot with what is considered to be an offering of cereals.

The sediment in the pits ranged from sticky loam to fairly gravelly loam, rich in calcareous matter. Froth flotation was used for the separation of the late Iron Age and Gallo-Roman samples provided by the University of Durham, England. The others were hand-sieved. Meshes used went down to $0.25 \mathrm{~mm}$.

The state of preservation of Neolithic fruits and seeds was rather bad. It was poorer than in the loess-covered areas in Germany and the Netherlands with which I am familiar. The coarser and very calcareous soils of the Aisne valley may be at the root of this difference. From the late Bronze Age onwards the preservation is good.

I used samples from the following localities, all rural sites, if not indicated otherwise:

1. Cuiry-lès-Chaudardes "Les Fontinettes": Bandkeramik, Michelsberg, Hallstatt C (Soudsky et al. 1982; Ilett et al. 1982; first botanical results Bakels 1984).

2a. Bucy-le-Long "La Fosse Tounise": Bandkeramik, Villeneuve-St. Germain (Ilett et al 1995; botanical results Bakels 1995).

2b. Bucy-le-Long "Le Grand Marais"/"Le Fond du Petit Marais": Villeneuve-St. Germain

3a. Berry-au-Bac "Le Chemin de la Pêcherie": Bandkeramik (llett and Plateaux 1995, with a contribution by, among others, Bakels).

3b. Berry-au-Bac "Le Vieux Tordoir": Cerny, Hallstatt C, La Tène A.

4. Menneville "Derrière le Village": Bandkeramik, La Tène A (Coudart and Demoule 1982; botanical results Bakels 1984).

5. Villeneuve-St. Germain: Villeneuve - St. Germain culture, La Tène D (valley bottom oppidum) (Debord 1982; first botanical results Bakels 1984).

6. Trosly-Breuil: Villeneuve - St. Germain.

7. Juvincourt-et-Damary: Cerny.

8. Bazoches-sur-Vesle: Michelsberg causewayed camp.

9. Compiègne "Le Fond Pernant": early Bronze Age, late Bronze Age, La Tène A (botanical results Bakels 1984).

10. Vieux-Moulin "St. Pierre-en-Chastre": late Bronze Age, small vessel with carbonized seeds (Blanchet 1984 p. 265; botanical results Bakels 1984).

11. Beaurieux "Les Grèves": Hallstatt D, La Tène C/D, D, early Gallo-Roman, Haut Empire, Bas Empire (Haselgrove 1996).

12. Damary "Le Ruisseau de Fayau": La Tène C/D (Haselgrove 1996).

13. Soupir "Le Parc": La Tène C/D (Haselgrove 1996).

14. Condé-sur-Suippe: La Tène D (valley bottom oppidum).

15. Champlieu: 4th Century A.D. (Bakels et al. 1986; botani cal results Bakels 1984).

16. Cerny-en-Laonnois: 6th Century A.D. (large silo). 


\section{Results}

As mentioned above, some of the botanical material has already been published. In the following these results will be combined with data as yet unpublished (Tables $1,2)$.

It is clear that not every archaeological period could be covered and that the data are not evenly distributed over the span of time. No samples were available from late Rössen settlements. The Seine-Oise-Marne culture, Bell Beaker culture and Bronze Age are mainly known by their funerary monuments, which is the reason for the absence of finds from these periods. Hallstatt D merged with La Tène $A$ in the dates provided with the samples. In northern France the periods into which La Tène is divided are the subject of debate, which is the reason why no finds are attributed to La Tène $B$.

The first crops produced in the Aisne valley comprise naked barley (Hordeum vulgare var. nudum), emmer wheat (Triticum dicoccum), einkorn wheat (Triticum monococcum), lentil (Lens culinaris) and pea (Pisum sativum). Four of those are common Bandkeramik crops. The exception is naked barley, which was not common in every region occupied by the Bandkeramik people. The region nearest to the Aisne valley where naked barley was regularly grown, is the Neckar district in Germany. The cultural affinities of the Aisne Bandkeramik are indeed sought for in the east and not in the northeast, where the Belgian/Dutch/German Rhineland Bandkeramik is situated, a loess region with very few incidences of barley. A cultural link with the Neckar district might have brought barley as a main crop to our valley, bypassing the upper Rhine district and Lorraine where naked barley has not yet been found. Another possibility is that the soils and/or micro-climate of the barley-growing regions were not as good as in the more classic loess districts (Sielmann 1972). Barley can stand adverse conditions better than emmer and might thus have induced farmers to grow more of the crop than elsewhere.

Conspicuously absent is linseed (Linum usitatissimum), an otherwise quite common plant in the Bandkeramik. Poppy (Papaver somniferum) was hoped for in view of its presumed west Mediterranean origin (Bakels 1982). In the Aisne valley the first poppy appears, however, in the Michelsberg culture, a cultural horizon in which the plant was already grown all over Europe.

The Villeneuve-St. Germain crops are the same as those of the Bandkeramik. I set not much store by the absence of lentil. The result is in accordance with other cultural traits of Villeneuve-St.Germain. The culture is described as developed out of the Bandkeramik (Ilett et al. 1995).

The Cerny culture brings a new element: naked wheat. Although both samples and seeds from this culture are not very numerous, this wheat was the commonest find in the Cerny settlements. Only grains were found, but I assume, on account of the presence of Triticum aestivum in the contemporaneous Rössen culture, with which cultural contacts existed, that the Cerny naked wheat is bread wheat too. The Cerny culture is known to have introduced many new cultural elements in the area (Constantin et al. 1997). Growing bread wheat as a main crop was one of these new traits (Bakels 1997). From this time onwards the cereal was presumably regularly sown in the Aisne valley.

The Michelsberg culture comes with hulled barley (Hordeum vulgare) instead of naked barley, but as long as the barley grown by the Cerny and the late Rössen people, which is unfortunately missing from the records and therefore remains unknown, it is impossible to ascribe the appearance of hulled barley to the Michelsberg culture. I presume that the Cerny and late Rössen cultures grew barley as did the cultures before and after them.

There follows an important time gap. The Chalcolithic is unknown and the information concerning the Bronze Age is scarce. Nevertheless, the first millet (Panicum miliaceum) is recorded here.

From the Iron Age onwards information becomes satisfactory again. In comparison with previous periods the range of crop plants has grown considerably. Iron Age farms produced hulled barley, bread wheat, emmer, einkorn, spelt (Triticum spelta), millet, lentil, pea, bitter vetch (Vicia ervilia), "Celtic" bean (Vicia faba var. minor), gold of pleasure (Camelina sativa) and poppy. In La Tène $\mathrm{C}$ and $\mathrm{D}$ contexts oat (Avena sp.) was found in such quantities that oat must have been grown although the scanty remains of floret bases are those of $A$. fatua. Oat grains were found before La Tène $\mathrm{C}$, but in such low quantities that they have not been entered into the list of crop plants before this time.

The La Tène C/D site of Damary contained the first (and only) kitchen herb: celery (Apium graveolens). La Tène D brought the first linseed (Linum usilatissimum) of the valley.

The diversification in crops seems to have begun, as far as can be deduced from the data, in the Hallstatt $C$ period. This is not a particularity of the Aisne valley. Other parts of Europe show a similar development, but slightly earlier, with the onset of the Late Bronze Age (Küster 1991; Jones 1996, p 31 ). However, as mentioned above, the Aisne valley Hallstatt $\mathrm{C}$ is not very easily distinguishable from the Late Bronze Age, and the phenomenon might share the same background.

The diversification seems to be linked with a general change in society. Some authors think of an economic crisis caused by population growth. Over-exploitation of the available land should have forced people to adopt a new attitude to the ownership and use of land (Pommepuy and Robert 1991, p 101, Champion et al. 1984, p 280). Others look for more social and ideological reasons. A splitting up of large households into nuclear families might have taken place, implying new ways of tilling fields and raising animals (Fokkens 1997). A more intensive use of arable land, with a widening of the range of plants grown, goes well with both views.

The Gallo-Roman period is a continuation of the La Tène period, but for two exceptions. Camelina (gold of pleasure) has disappeared from the record. The abandonment of this plant is seen, too, in other regions where a rural population became Romanized, Oss-Ussen in the Netherlands for instance (Bakels et al. 1997). New is the cultivation of rye (Secale cereale). In Champlieu it was 
Table 1. The cultivated plants. Ns Number of samples; Av Avena sp.; Hn Hordeum vulgare var. nudum; Hv Hordeum vulgare var. vulgare; Pm Panicum miliaceum; Ta Triticum aestivum; Td Triticum dicoccum; Tm Triticum monococcum; Ts Triticum spelta; Sc Secale cereale; Lc Lens culinaris; Ps Pisum sativum; Ve Vicia ervilia; Vf Vicia faba var. minor; Vs Vicia sativa ssp. sativa; Cs Camelina sativa; Lu Linum usitatissimum; $\mathrm{Pa}$ Papaver somniferum. Nc number of cultivated species; $\mathrm{Ng}$ number of gathered species; Nh number of herbs; * = Apium graveolens included

Ns Av Hn Hv Pm Ta Td Tm Ts Sc Le Ps Ve Vf Vs Cs Lu Pa Ne Ng Nh

\section{Bandkeramik}

Cuiry-lès-Chaudardes

Bucy-le-Long BFT

Berry-au-Bac BCP

Menneville

Villeneuve St.-Germain

Villeneuve St.-Germain

Trosly-Breuil

Bucy-le-Long BFT

Bucy-le-Long BGM/BFM

Cerny

Berry-au-Bac BVT

Juvincourt

Michelsberg

Bazoches

Cuiry-lès-Chaudardes

early Bronze Age

Compiègne

late Bronze Age

Compiègne

Vieux-Moulin

Hallstatt C

Berry-au-Bac BVT

Cuiry-lès-Chaudardes

Hallstatt D/La Tène A

Berry-au-Bac BVT

Menneville

Beaurieux

Compiègne

La Tène C/D

Beaurieux

Damary

Soupir

La Tène D

Beaurieux

Condé-sur-Suippe

Villeneuve St.-Germain

1st century A.D.

Beaurieux

2nd-3rd century A.D.

Beaurieux

3rd-4th century A.D.

Beaurieux

Champlieu

5th-6h century A.D.

Cerny-en-Laonnois

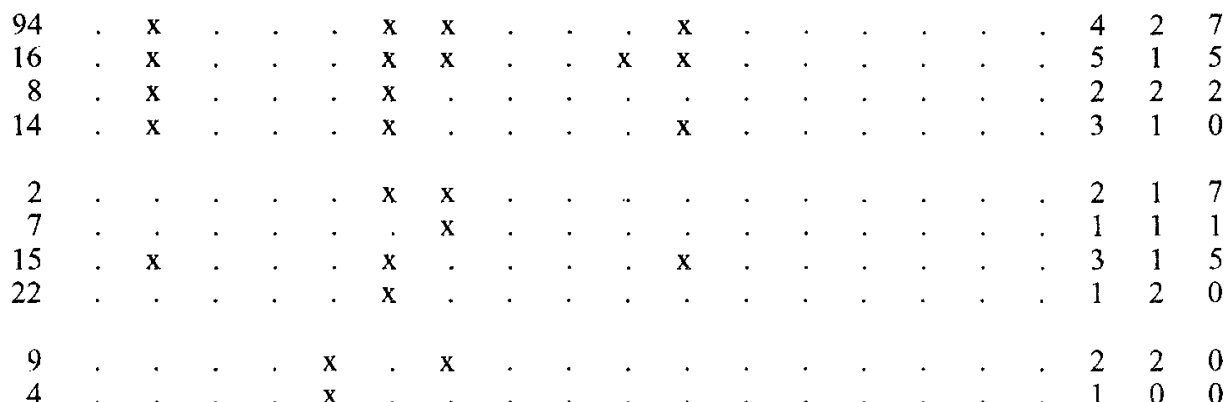

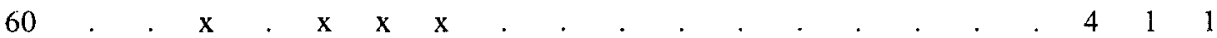

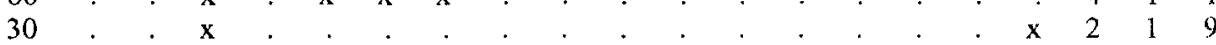

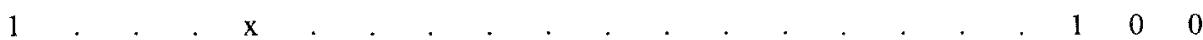

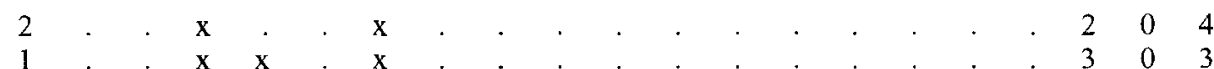

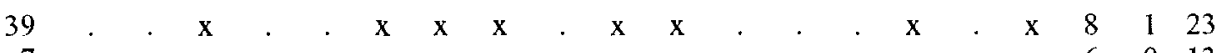

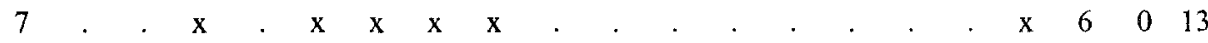

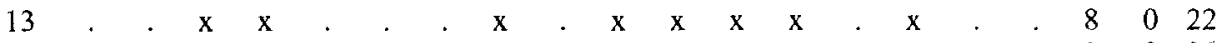

$1 . \quad \mathrm{x} . \quad \mathrm{x} . \mathrm{x} . \quad . \quad . \quad . \quad . \quad 3026$

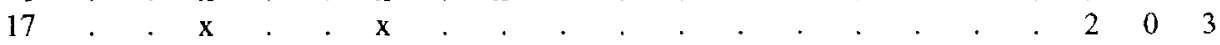

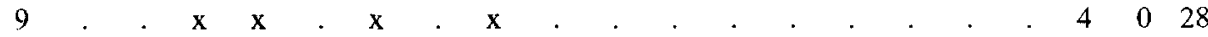

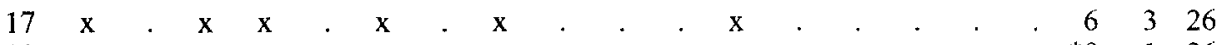

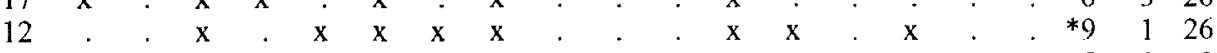

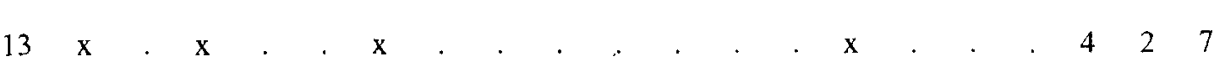

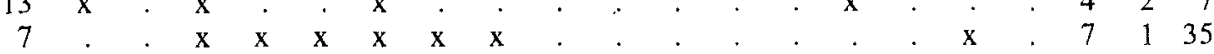

$33 . \quad . \quad \mathrm{x} . \quad . \quad . \quad . \quad . \quad . \quad . \quad . \quad 214$

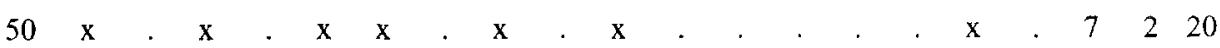

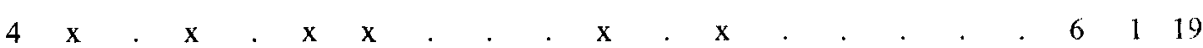

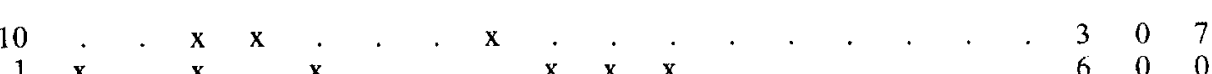

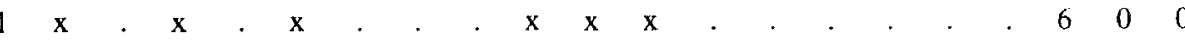

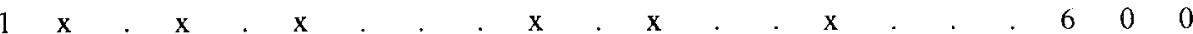

already a main crop. I have suspicions, as yet not wellfounded, that rye was introduced rather late, perhaps in the 4 th century A.D. Future research should prove this. Whether the Roman conquest brought new products, remains unknown. Perhaps there was something grown especially for Romans and the truly Romanized élite, but the traces are absent. The reason might be that those products were of a kitchen herb and vegetable nature, and did not readily leave carbonized remains.

The last two columns of Table 1 show the number of wild plants. The woody taxa are entered as $\mathrm{Ng}$. They concern fruits and nuts gathered in the wild. Where only one species is mentioned, the species in question is hazelnut (Corylus avellana). A second one means sloe (Prunus spinosa), except for the Villeneuve-St. Germain site of Bucy-le-Long "Le Grand Marais" where apple (Malus sylvestris) is concerned. The third species, in a La Tène C/D site, is hawthorn (Crataegus monogyna).

The herbs $(\mathrm{Nh})$ are specified in Table 2. In order to avoid unwieldy tables, information is given on the level of the archaeological culture. Cultures with an absence or near absence of herbs in the available data are not entered. The Gallo-Roman period is presented as one single unit. 
Table 2. List of wild herbs, indeterminatae excluded. Ba Bandkeramik; VSG Villeneuve-St.-Germain; Mic Michelsberg; HaC Hallstatt C; TA Hallstatt D/La Tène A; TCD La Tène C/D; TD La Tène D; G-R Gallo-Roman

Ba VSG Mic HaC TA TCD TD G-R

Fields and Gardens
Agrostemma githago
Anagallis arvensis
Apera spica-venti
Aphanes microcarpa
Arenaria serpyllifolia
Atriplex patula/prostrata
Brassica sp./Sinapis arvensis
Bromus arvensis
Bromus hordeaceus/secalinus
Bromus sterilis/tectorum
Buglossoides arvensis
Bupleurum rotundifolium
Chenopodium album
Chenopodium hybridum
Chenopodium polyspermum
Digitaria ischaemum
Echinochloa crus-galli
Fallopia convolvulus
Galeopsis speciosa/tetrahit
Galium aparine
Galium spurium
Galium tricomutum
Lapsana communis
Papaver argemone
Papaver dubium/rhoeas
Persicaria lapathifolia
Sambucus ebulus
Scleranthus annuus
Setaria viridis/verticillata
Sherardia arvensis
Solanum nigrum
Stachys arvensis/sylvatica
Thlaspi arvense
Valerianella dentata
Vicia hirsuta
N

and

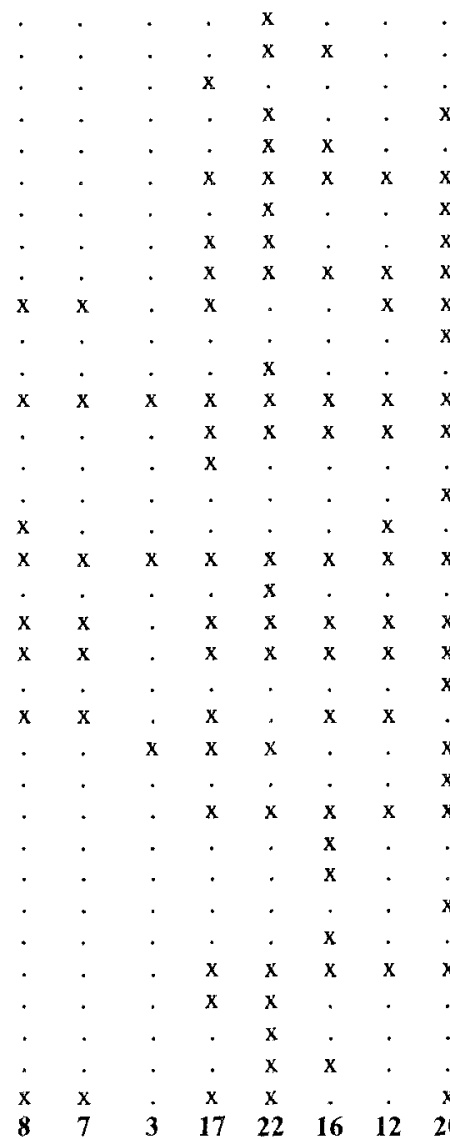

Ruderal places

Artemisia vulgaris Capsella bursa-pastoris Chenopodium ficifolitum Malva neglecta/sylvesiris Matricaria maritima Medicago lupulina Melilotus sp.

Picris hieracioides Plantago major

Poa annua

Polygonum aviculare Saponaria officinalis

Silene dioica/latifolia Sisymbrium officinale

Tanacetum vulgare

Verbascum sp.

Verbena officinalis N

Grasslands

Alchemilla sp.

Alopecurus sp.

Bromus racemosus

Centaurea scabiosa

Daucus carota

Euphrasia sp./Odontites sp.

Festuca ovina
Ba VSG Mic HaC TA TCD TD G-R

Festuca pratensis

Festuca rubra

Hieracium subgen. Pilosella

Hypericum perforatum

Knautia arvensis

Leucanthemum vulgare

Lolium sp. (non temulentum)

Lotus corniculatus

Phleum pratense

Pimpinella saxifraga

Plantago lanceolata

Poa sp. (non annua)

Rumex acetosella

Satureja acinos

Silene conica/mutans

Trifolium dubium type

Trifolium repens

Veronica arvensis

Wetlands

Eleocharis palustris

Galium palustre

Leersia oryzoides

Mentha aquatica/arvensis

Persicaria hydropiper

Persicaria minor

Ranunculus repens

Scirpus lacustris

Sparganium erectum

Stellaria uliginosa

$\mathrm{N}$

Ecologically indeterminate

Centaurea sp.

Cirsium sp.

Medicago/Melilotus/Trifolium

Myosotis sp.

Potentilla sp.

Rumex sanguineus

Rumex sp.

Stellaria sp.

$\mathrm{N}$

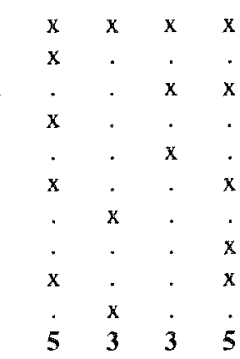

The list is divided into four groups: plants from fields and gardens, plants from ruderal places and paths, plants from grassy areas and plants from wet surroundings. The classification is based on the Liste courante provisoire des plantes vasculaires du departement Aisne 1981 (Mennema 1981), but with modifications. Plants, which are commonly associated with carbonized cereals, are listed as field weeds, although the "Liste" describes them as ruderals or even woodland species. Examples are Chenopodium album, Bromus sterilis/tectorum, Galium aparine and Lapsana communis. This illustrates the difficulty in arranging groups when working with plants from the past. As a matter of fact, Table 2 presents a kind of continuum, running from true field weeds (Agrostemma githago, for instance), to plants from fallow fields and ruderal places, then to grassland components, and ending with watersides (Sparganium erectum). The division is somehow artificial, but it helps in getting to grips with a long list.

The eight field weeds of the Bandkeramik are common finds in this culture. The most frequently occurring species in the Aisne valley are Fallopia convolvulus, 
Lapsana communis, Galium aparine and G. spurium, and Bromus sterilis/tectorum. Nevertheless, just as in the case of the crop plants, the assemblage has a distinct regional face, which differs from, for instance, the Rhineland (and adjacent Netherlands and Belgium) and Bavaria in Germany. Missing are Bromus hordeaceus/ secalinus, very common in the Rhineland and Bavaria, Persicaria maculosa (syn. Polygonum Persicaria), very common in the Rhineland but absent in Bavaria, Solanum nigrum and Setaria viridis/verticillata, common in Bavaria but absent in the Rhineland (Knörzer 1971, Bakels 1992). It is clear that, also where wild herbs are concerned, the Bandkeramik culture has known agricultural provinces.

The Villeneuve-St.Germain culture shows the same picture as the Bandkeramik, exactly as was expected.

Lack of data makes it impossible to look for possible new weeds in the innovative Cerny culture. The Michelsberg culture is not very informative either, due perhaps partly to the fact that many samples came from the ditches of a non-rural place - a causewayed camp -, which were very poor in plant remains. Nevertheless, the truly rural site of Cuiry-lès-Chaudardes was not very rich in plant remains either.

The contrast in number of species between the Neolithic on the one side and the Iron Age and GalloRoman period on the other, is striking. If the contrast had been only visible in wild plants, the difference might have been put down to better preservation of carbonized seeds and fruits in younger contexts. Better preservation does not only mean a better chance of finding fragile taxa, but also more specimens, and more specimens enhance the possibility of finding more taxa. The increase in numbers of wild plants is, however, matched by the increase in number of crop plants. Most of these are rather robust. Their presence is considered to be less dependent on preservation than that of the wild herbs. The difference is, therefore, real. Moreover, the same trend is reported from other regions with better preservation (Knörzer 1976).

The increase is not only seen in weeds from fields and gardens, but also in ruderals, in grassland plants, and, very striking, in wetland plants. These kinds of plants were obviously, from at least Hallstatt $\mathrm{C}$ onwards, brought to settlements and had chances of getting charred there. What is the cultural background of this behaviour? Most species are good fodder plants and one of the explanations is that a change in animal husbandry, implying an increased use of fodder in the settlements, has brought the change about. At the same time the surface of deforested areas might have been enlarged, creating more pastures, and even some meadows at the waterside. A similar development is reported by Knörzer (1975) for the Rhineland and by Behre and Jacomet (1991, p 85), and van Zeist (1991, p 123) for western and central Europe in general. Something resembling true hay has been found in Condé-sur-Suippe, and an increased use of fodder based on grass and accompanying herbs might account for much of the increase in species. It is, however, not the only explanation.

A second possibility is that more herbs came in with the crops. A change in harvesting methods, cutting lower on the stalk, or uprooting, would result in more herbs being transported to the settlement. Both methods imply the harvesting of low-growing weeds.

The list of field and garden weeds comprises ten species which never reach heights above $30 \mathrm{~cm}$ (De Langhe et al. 1978). These species are Anagallis arvensis, Aphanes microcarpa, Arenaria serpyllifolia, Bupleurum rotundifolium, Galium tricornutum, Papaver argemone, Scleranthus annuus, Sherardia arvensis, Stachys arvensis and Valerianella dentata. Of these only $P_{a-}$ paver argemone occurs before the Iron Age. La Tène A and $\mathrm{C} / \mathrm{D}$ have an especially large share with respectively $27 \%$ and $40 \%$ of low-growing weeds. Seeds of these species are found mixed with cereal grains in the primary fill of silos, which implies that the grain was indeed cut not far above the ground (or uprooted). The fact that the complete stalk was brought in, can only be explained by some use for straw, as animal fodder or something else.

A change in harvesting methods does, however, not account for all increase in weed species numbers. The fields seem to have been weedier than before and changes in other agricultural practices have to be looked for as well.

Next to harvesting methods, weed vegetations are influenced by the cleaning of crop seed, by manuring, by changes in fallow systems or by artificial flooding (Poschlod and Bonn 1998). If artificial flooding is disregarded, because it is unknown in this region, the cleaning of sowing seed, manuring and fallowing are left. More carelessness in cleaning is archaeologically hard to prove, but also hard to accept. An increase in manuring with household waste and animal dung is more plausible. It would bring more viable seeds of new species, originating from a variety of habitats, on to the fields. A change in the length of fallowing would change the composition of the weed flora in the seed bank. A shortening of the fallow period, for instance, would increase the number of herb species; species with short-term persistent seeds would get the chance to survive in the seed bank and to establish themselves.

I have tried to see whether manuring could have played a role by looking for an increase of species with a high requirement for nitrogen. Such an increase was not seen, but neither was a decrease. Soils seem to have lost none of their fertility, but whether this is because of manuring cannot be assessed. An occasional flooding by river water, restoring fertility, cannot be excluded. The question can better be answered by investigations elsewhere, in regions out of the reach of river water.

Both manuring and short-term fallowing would fit well into the ideas concerning the intensification of land use mentioned above.

According the small sample that I have studied, the impact of the Roman conquerors on local agricultural practices seems to have been negligible.

\section{Conclusion}

According to the present state of knowledge concerning the pre- and protohistory of the Aisne valley, its population has known three major changes in food agricultural practices. 
The first was the introduction of crop cultivation. It was based on three cereals and two pulses, and practised by people belonging to the Bandkeramik culture. Their agriculture formed a definite "province" within the panEuropean Bandkeramik world.

The second change was the introduction of naked wheat by the Cerny culture. This culture brought many new customs to the Aisne valley, but the knowledge of its agriculture is still too scanty to assess the true importance of its innovations in food economy.

The third major change occurred in the late Bronze Age and/or early Iron Age. It formed part of a European development towards more diversification in crops, more intensive use of fields and the appearance of traces of pasture land. People cultivated seven cereals, four pulses and two oil plants. The list of wild plants entering settlement sites, and getting carbonized there, grew considerably. The species concerned were mainly weeds from crops and plants from open, grassy, spaces.

Acknowledgments. I should like to thank all colleagues who provided me with the basis on which this paper is founded: the samples. I cannot name them all, but Mike Ilett, Claude Constantin, Jérôme Dubouloz, Jean-Paul Farruggia and Colin Haselgrove almost buried me under their contributions.

\section{References}

Bakels CC (1982) Der Mohn, die Linearbandkeramik und das westliche Mittelmeergebiet. Archäol Korrespondenzbl 12; $11-13$

Bakels CC (1984) Carbonized seeds from northern France. Analecta Praehist Leidensia 17: 1-25

Bakels CC, Durand M, Foucray B, Tuffreau-Libre M (1986) Le terroir de Champlieu (Oise) (IVème - XVIIIème siècles). Revue Archéologique de Picardie 1986, 1-2: 35-152

Bakels CC (1992) Fruits and seeds from the Linearbandkeramik settlement at Meindling, Germany, with special reference to Papaver somniferum. Analecta Praehist Leidensia 25: 55-68

Bakels CC (1995) Bucy-le-Long "La Fosse Tounise/La Héronnière" et la continuité Rubané - Villeneuve-Saint-Germain: l'apport de l'analyse des graines carbonisées. In: Ilett M, Constantin C, Farruggia J-P (eds) Bâtiments voisins du Rubané et du Groupe de Villeneuve-Saint-Germain sur le site de Bucy-Le-Long "La Fosse Tounise" (Aisne). Rev Archéol Picardie No. spécial 9: 37-38

Bakels C (1997) Le blé dans la culture de Cerny. In: Constantin C, Mordant M, Simonin D (eds) La Culture de Cerny. Mém Musée Préhist Ille-de-France 6, pp 315-317

Bakels C, Wesselingh D, Amen I van (1997) Acquiring a taste: the menu of Iron Age and Roman-period farmers at Oss-Ussen, the Netherlands. Analecta Praehist Leidensia 29: 193-211

Behre K-E, Jacomet S (1991) The ecological interpretation of archaeobotanical data. In: Zeist W van, Wasylikowa $\mathrm{K}$, Behre K-E (eds) Progress in old world palaeoethnobotany, Balkema, Rotterdam, pp 81-108

Blanchet J-C (1984) Les premiers métallurgistes en Picardie et dans le Nord de la France. Mém Soc Préhist Française 17

Champion T, Gamble C, Shennan S (1984) Prehistoric Europe. Academic Press, New York
Constantin C, Mordant D. Simonin D (1997) La Culture de Cerny, nouvelle économie, nouvelle société au Néolithique. Mém Mus Préhist Ile-de-France 6

Coudart A, Demoule J-P (1982) Le site néolithique et chalcolithique de Menneville. Rev Archéol Picardie No. spécial 1982: 129-147

Debord J (1982) Premier bilan de huit années de fouilles à Villeneuve-Saint-Germain (Aisne). Rev Archéol Picardie No. spécial 1982: 213-264

Fokkens H (1997) The genesis of urnfields: economic crisis or ideological change?. Antiquity 71: 360-373

Haselgrove C (1996) La romanisation de l'habitat rural dans la vallée de l'Aisne d'après les prospections de surface et les fouilles récentes. Rev Archéol Picardie No. spécial 11: 109-120

Ilett M, Constantin C, Coudart A, Demoule J-P (1982) The Late Bandkeramik of the Aisne valley: environment and spatial organisation. Analecta Praehist Leidensia 15: 45-61

Ilett M, Constantin C, Farruggia J-P (1995) Bâtiments voisins du Rubané et du Groupe de Villeneuve-Saint-Germain sur le site de Bucy-Le-Long "La Fosse Tounise" (Aisne). Rev Archéol Picardie No. spécial 9: 17-39

llett M, Plateaux M (1995) Le site néolithique de Berry-au-Bac "Le Chemin de la Pêcherie" (Aisne). Monographie du CRA 15, CNRS éditions, Paris

Jones M (1996) Plant exploitation. In: Champion TS, Collis JR (eds) The Iron Age in Britain and Ireland: recent trends. Collis, Sheffield, pp 29-40

Knörzer K-H (1971) Urgeschichtliche Unkräuter im Rheinland, ein Beitrag zur Entstehungsgeschichte der Segetalgesellschaften. Vegetatio 23: 89-111

Knörzer K-H (1975) Entstehung und Entwicklung der Grünlandvegetation im Rheinland. Decheniana 127: 16-214

Knörzer K-H (1976) Datienung durch Grossrestanalyse. Folia Quat 47: 57-62

Küster H. (1991) Mitteleuropa südlich der Donau, einschliesslich Alpenraum. In: Zeist W van, Wasylikowa K, Behre K.-E (eds) Progress in old world palaeoethnobotany. Balkema, Rotterdam, pp 179-187

Langhe J de, Delvosalle L, Duvigneaud J, Lambinon J, Berghen C vanden (1978) Nouvelle flore de la Belgique, du Grand-Duché de Luxembourg, du Nord de la France et des régions voisines, 2nd edn. Patrimoine du Jardin botanique national de Belgique, Meise

Mennema J (1981) Liste courante provisoire des plantes vasculaires du département Aisne (France). Rijksherbarium, Leiden

Pommepuy C, Robert B (1991) Archéologie d'une vallée. Association pour le Développement du Musée de Soissons, Soissons

Poschlod P, Bonn S (1998) Changing dispersal processes in the central European landscape since the last ice age: an explanation for the actual decrease of plant species richness in different habitats? Acta Bot Neerl 47: 27-44

Sielmann B (1972) Die frühneolithische Besiedlung Mitteleuropas. Fundamenta A/3: 1-65

Soudsky B, Bayle D, Beeching A, Bicquard A, Boureux M, Cleuziou S, Constantin C, Coudart A, Demoule J-P, Farruggia J-P, Ilett M (1982) L'habitat néolithique et chalcolithique de Cuiry-lès-Chaudardes "Les Fontinettes-Les Gravelines". Rev Archéol Picardie No. spécial 1982: 57-119

Zeist W van (1991) Economic aspects. In: Zeist W van, Wasylikowa K, Behre K-E (eds) Progress in old world palaeoethnobotany. Balkema, Rotterdam, pp 109-130 